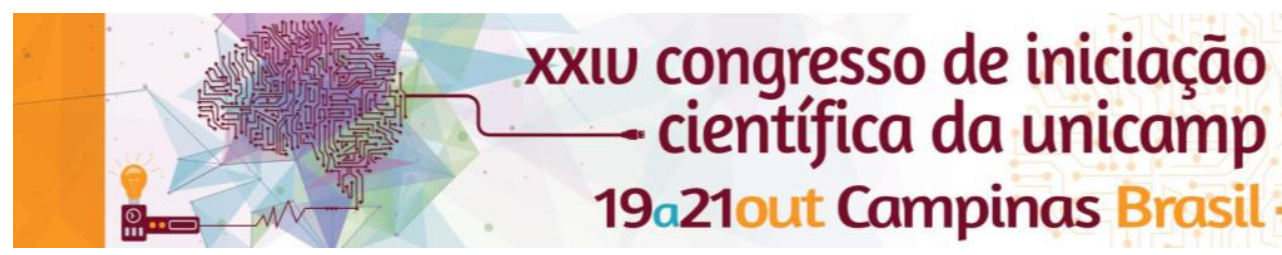

\title{
Aplicação de Tecnologia BIM em Projeto para HIS autogerida: explorando alternativas.
}

\author{
Autores: Robson Fernando de Jesus Pereira*; Eloisa Dezen-Kempter.
}

\section{Resumo}

Este projeto abordou dois temas relevantes: Habitação de Interesse Social (HIS) e a tecnologia de modelagem da informação da construção (Building Information Modeling- BIM). Trata-se de uma pesquisa aplicada a um caso de estudo, o Bairro Geada, localizado no município de Limeira - SP. Este bairro apresenta duas formas habitacionais: um conjunto de 395 casas térreas de tipologia padrão, construídas com recursos do programa Minha Casa Minha Vida; e 380 lotes que fazem parte do programa de lotes urbanizados, nos quais os moradores planejam, projetam e constroem suas casas sem qualquer suporte técnico. As construções HIS autogerida no país tem sido alvo de pesquisas que visam melhorar a qualidade do projeto, abordando principalmente conceitos como adaptabilidade, ampliabilidade e flexibilidade. O BIM é uma tecnologia da informação e comunicação, voltada para a área de Arquitetura, Engenharia e Construção (AEC) com a finalidade de melhorar a colaboração entre atores e 0 armazenamento de dados no processo de concepção e gerenciamento de projetos e construção.

\section{Palavras-chave \\ Habitação de Interesse Social, BIM, Autogeria.}

\section{Introdução}

O projeto busca aliar duas questões no contexto atual na construção civil brasileira: a precariedade das Habitações de Interesse Social (HIS) autogeridas e o uso de tecnologias da informação, como Building Information Modeling(BIM). O objetivo geral desta IC é o desenvolvimento de um protótipo para Habitação de Interesse Social, que englobe os conceitos adaptabilidade, ampliabilidade e flexibilidade, visando apoiar os processos de construção autogerida no bairro Geada, atendendo as necessidades de moradores locais.

\section{Resultados e Discussão}

Foram realizados levantamentos de dados para pesquisa junto com a comunidade local, para saber as técnicas construtivas, modificações dos imóveis originais e se os imóveis atende a necessidade das famílias. Essas informações constituirão a base para propor um modelo de habitação de interesse social autogerida.

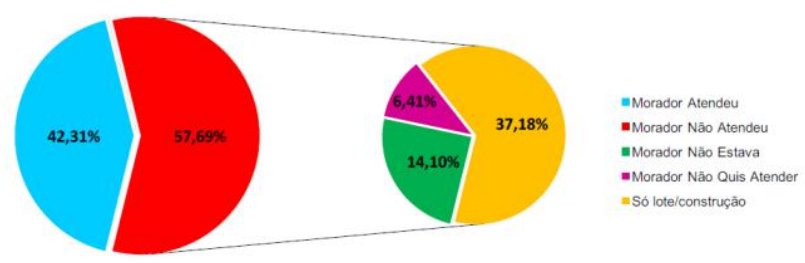

Gráfico 1 - Porcentagem de lotes abrangidos.

Logo após coletada as primeiras informações do bairro Geada, iniciamos um treinamento com o Software Autodesk Revit 2015 (Figura 3) visando trabalhar conceitos e aplicações do programa e da modelagem BIM (Building Information Modeling).

O programa utiliza a extensão RVT para armazenar seus arquivos. As famílias, também chamados de componentes paramétricos, são guardadas no formato RFA, assim oferecendo um sistema gráfico, aberto para a concepção do projeto e realização da forma, bem como a oportunidade de expressar a intenção do desenho em níveis crescentes, detalhadamente.

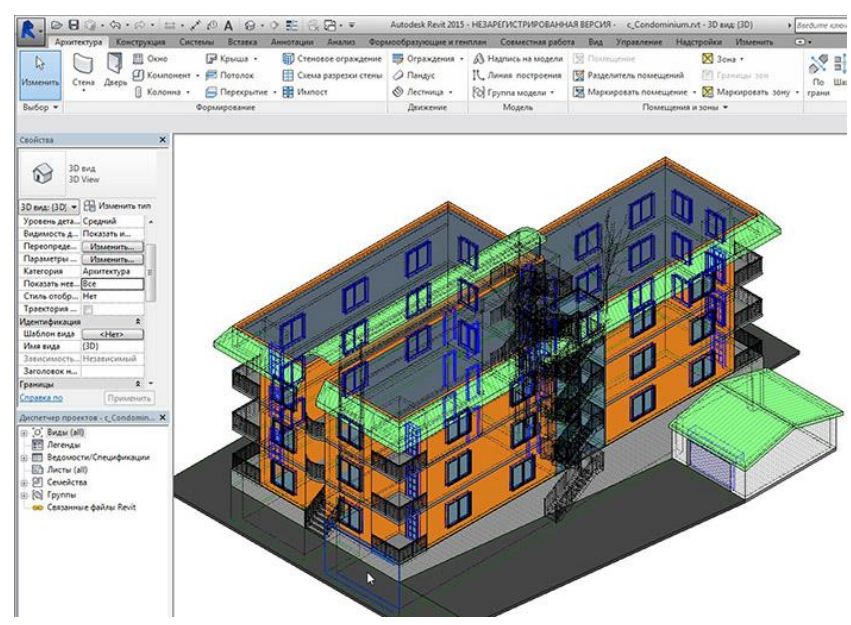

Figura 1 - Imagem do Software Autodesk Revit 2015

\section{Conclusões}

A relação Universidade, Poder Público e Comunidade mostrou-se bastante produtiva. Esperamos com esse projeto um melhor aproveitamento do uso de materiais na construção HIS autogerida e atendendo as necessidades básicas dos moradores locais. A Universidade pode colaborar de forma efetiva na instrução técnica, que certamente resultará a médio e longo prazo na melhora da qualidade do Bairro Geada e podendo ser implementando em outras Habitações de Interesse Social.

\section{Agradecimentos}

Agradeço a todos os alunos do Proext, à Professora Dra. Eloisa e Mestranda Nathalia Trevisan pela ajuda na elaboração desta IC. 